\title{
The Construction of "Tunisianity" through Sociolinguistic Practices from the Tunisian Independence to 2016
}

\author{
MARIEM GuELlouz (Université Paris Descartes)
}

\begin{abstract}
In the period following the revolutionary events in Tunisia, several linguistic issues were put at the core of political life. While some conservative political activists called for the institutionalisation of the Arabic standard language, others highlighted the importance of the Tunisian dialect as a mother tongue, while Berber activists fought for a broader recognition of the Tamazight language. As they are connected with identity and belonging, these linguistic issues raise the following questions: What language does a Tunisian have to speak in order to be considered a Tunisian? How do sociolinguistic practices contribute to the construction of "Tunisianity"?
\end{abstract}

\section{Introduction}

After the 2011 revolutionary movements in Tunisia, debates within the media and civil society highlighted the issue of "Tunisianity". Some slogans such as "Be proud you are Tunisian" or "I am Tunisian and let them say I am crazy" or "Be happy you are a Tunisian" circulated in the media and were used in political discourse. "Tunisianity" emerged as a new central concept in a period of democratic transition. People seemed to reflect on the meaning of being a Tunisian, and linguistic issues were put at the core of political life. While some conservative political activists called for the institutionalisation of the Arabic standard language, others stressed the importance of the Tunisian dialect as a mother tongue, while Berber activists fought for a broader recognition of Tamazight. In political debates, some deputies were strongly criticized because of their use of French. Social media users mocked the linguistic mistakes made by the politicians. As they are connected with identity and belonging, these linguistic issues raise the following questions: What language does a Tunisian have to speak in order to be considered a Tunisian? Why is it that the most emblematic word of the Tunisian revolution was the French word "dégage"? How can we define "Tunisianity" linguistical$1 y$ ? What is the place of French in the political debate?

These questions have their roots in Tunisian history. After the independence of March $20^{\text {th }}, 1956$, linguistic issues were part of the political and social debates about the construction of a national identity. In his speech of July $29^{\text {th }}$, 1968 , President Bourguiba announced to Tunisian citizens: "[...] Arabic is not the language of the Tunisian people". Starting from this statement, Tunisia has a long history of linguistic and political confrontation since its independence (RIGUET 1984). This also marks a linguistic contradiction which I am going to analyze in this article. It is important in this respect to go back to the linguistic policies that were widely undertaken during the French colonial period (1881-1956) in order to study their role in the construction of "Tunisianity". As for 2016, the target year of the In 2016 project, 
educational reforms, Arabization, the teaching of the Koran and the debate on the use of French in political speeches were the main linguistic issues observed in Tunisia during this year. They highlight the connection between social hierarchization, language practices and the nation-state (HELLER 2008). Before exploring these linguistic conflicts and their links to identity struggle, I would like to recall the linguistic issues that Tunisia witnessed before and after the 2011 revolution. I will focus on the way these linguistic issues contribute to construct the image of "Tunisianness" or "Tunisianity". What is the link between linguistic issues and cultural codes regarding the construction of "Tunisianity" in 2016? How do language practices contribute to construct an image of "Tunisianity"? To answer these questions, we have to go back to the linguistic policies undertaken before the Tunisian revolution.

\section{Sociolinguistic issues in Tunisia}

Language practices in Tunisia should be analyzed as taking place in a battlefield that is linked to constitutional and political agendas. Indeed, language is not a homogeneous entity, but a practice connected with social cleavages, such as class, education and ideology. I will rely on Monica Heller's reflections on "identity" and "community" (HELLER 2008). I will also reconsider the construction of linguistic "Tunisianity" on the basis of Heller's theoretical perspective. In this context, Heller states:

I suggest that in the ideas of 'processes' and 'practices' we may find a conceptual basis for developing the tools we need to overcome the problems associated with traditional ideas of 'communities' and 'identities,' which require a focus on uniformized and relatively stable entities that are no longer of such concern to us today as they have been in the past. (HELLER 2008: 56)

After the colonial period, a feeling of national and Arab "pride" contributed to the consolidation of Standard Arabic as the language of the new Tunisian nation. The language of postcolonial "pride" was followed by that of "profit" and the consolidation of French as the language of openness towards Western countries, most notably France which is the main economic partner of Tunisia. The two notions of "pride" and "profit" have been developed and elaborated upon in several studies (HELLER \& DUCHÊNE 2012; GAL 2012).

It is important to recall that the first article of the 1959 Tunisian constitution declared Arabic as the official language of the country. The Tunisian constitution of 2014 retained this article, but specified that the official language is "classical Arabic". Nevertheless, according to Daoud 2011, what we call "Arabic" is a combination of linguistic uses of five main varieties: classical Arabic, literary Arabic, Modern Standard Arabic, educated Arabic and Tunisian Arabic ${ }^{1}$. Tunisian Arabic is the language of daily use in Tunisia. Modern Standard Arabic has a powerful position compared to Tunisian Arabic. According to Lotfi Sayahi,

the delicate position of Berber, the diglossic situation of Arabic and the increasing efforts for Arabization, the regional and social variation in Tunisian Arabic, the pres-

1 According to DAOUD 2011: 13, classical Arabic is the language of Qur'an. Literary Arabic refers to Arabic literature. Modern standard Arabic is an intermediate functional register. 
ence of French language and the gradual spread of English among other closelyrelated topics, constitute the core themes of research for Tunisian sociolinguistics. (SAYAHI 2011: 1)

It goes without saying that we cannot only reduce the analysis of this dilemma to the strict opposition between prestige and depreciation. We should rather study the diglossic situation between standard Arabic and Tunisian on the basis of more complex power relationships. The use of Modern Standard Arabic (MSA) or French situates the speaker in a certain position compared to other languages. These two languages require an important level of education and are only mastered by certain social classes in Tunisian society. Tunisian Arabic is not officially recognized as a national language and attitudes towards it may vary, ranging from a dream of authenticity (it would be the language of Tunisianity) to an elitist rejection (a dialect cannot be recognized as a language). In the Tunisian case, Berber is almost absent and the opposition lies between French and Arabic. These linguistic alliances and oppositions are linked to identity struggles.

Tunisian President Bourguiba (1957-1987) used a combination of Standard Arabic, Tunisian dialect and French in his public speeches. In 1961, he stated:

It is the French language that served me as a weapon to fight against French colonialism and bring it outside the Tunisian territory. The French language will still serve Tunisia to get rid of its underdevelopment and to catch up with modern countries. ${ }^{2}$

The quotation demonstrates two major points. First, the new Tunisian national movement held ambiguous attitudes towards the French language. President Bourguiba and other bilingual ruling elites of that period revealed this contradiction through their preference for the new bilingual educational system of college Saddīqiyya over the old Arabic-based educational system of Zaytūna University (NAFFATI \& QUEFFÉLEC 2004). The Tunisian elites were convinced that mastering French was part of the colonial fight against France. The second issue lies in the fact that President Bourguiba himself underlined the importance of speaking French in the construction of a modern country. In this way, modernity, progress, science and technology seemed to be and to remain linked to the French language.

Francophony was a constitutive part of the modernist political project supported by Bourguiba and the members of his government. In this context, the set of sources presented in the present contribution is very useful in order to highlight the speaker's representation of the language, or what Houdebine calls l'imaginaire linguistique (HOUDEBINE 2002). This "linguistic imagery" is embodied in the subjective relationship between the speaker and the language he/she uses. In fact, bilingual or multilingual situations have always been linked to political events in the history of Tunisia (LAROUSSI 1997). For example, after the arrest in France of President Ben Ali's brother for drug trafficking in 1999, the Tunisian government reacted very harshly, announcing an Arabization reform in all administrative fields. Francophony in Tunisia can be defined as a linguistic capital, in the sense Bourdieu has given to this concept (BOURDIEU 1982). This linguistic capital can, of course, have a higher or lower value, depending on the diplomatic relations with France. Essentially, as Gal points out,

$2<$ https://www.youtube.com/watch?v=U8xArsDS1J8\&t=304s>. 
the current phase of capital has important, specific effects. Indeed, the changing and expanding logic of capitalism and its encounters with political forms like ratio-state transform all aspects of the social world, including linguistic practices. (GAL 2012: 40)

Identity is at the core of this "linguistic market". Indeed, when political speeches call for a broader use and recognition of French, they focus on the fact that Tunisia has always been a country open to the world. They also highlight that, throughout history, several civilizations enriched Tunisia and that this makes French a determinant part of "Tunisianity". In contrast, when French is out of fashion, political speeches tend to highlight the primacy of ArabMuslim identity in Tunisia. According to Daoud,

Considering the modernist, pro-western/French socio-cultural model that Tunisian elites sought to build, it is clear that this elite considered the French language as an asset and a kind of war/colonization booty. This war will be entirely adopted as an ancillary communicative resource and a contributing element to build the country's identity. (DAOUD 2011: 19)

In fact, under repressive political regimes, linguistic Tunisianity was a fluctuant construction, depending on economic, political and diplomatic factors. The process of Arabization before the 2011 revolution has always been strongly linked to a violent repressive and dictatorial context. Since the independence in 1956, Tunisia has been torn between, on the one hand, a desire for the assertion of a post-colonial national identityand a modernist political project on the other. Ministers of Education played a decisive role in the policies of Arabization. In the 1970s, M. Mzali, the Minister of Education at that time, was a fervent supporter of an Arabization reform. He imposed the use of Arabic for natural sciences in secondary education, and this reform was followed by the Arabization of Humanities. This decision raised a wave of indignation and led to the massive resignation of philosophy teachers, who considered Arabic to be incompatible with the teaching of philosophy.

It is also important to notice that the Arabization of Humanities took place at the same time as the first political trials of young Marxist students. In this context, Arabization was a weapon of state control over leftist opponents. Mohamed Daoud holds that in Tunisia,

The Arabization process was poorly planned, hesitant and indeterminate, and still remains highly controversial. At the linguistic level, Arabization promoted the use of Arabic which involved some successful, though haphazard, corpus planning and positively impacted Arabic literacy. At the ideological level, Arabization helped reassert the country's Arab-Muslim identity. However, Arabization reforms were not wellreceived by everyone. (DAOUD 2011: 18)

In the political speeches of the ruling elites, some linguistic representations seem to bear a sharp division between languages: Arabic is presented as the language connected with ArabMuslim identity, while French as an expression of modernity. The socio-political context reveals that linguistic representations are linked to identity constructions that serve the nationstate. The stereotypical representations of languages are tools exploited by the propaganda. 


\section{Linguistic issues since the revolution}

In 2012, former president Marzouki used the expression "linguistic harissa" (a Tunisian sauce made of a mix of hot spices) to define the so-called "Arabizi"3 (GONZALEZ-QUIJANO 2012). The latter is a new form of digital writing Arabic used in digital networks, involving codeswitching and lexical/syntactical borrowing. Marzouki saw code-switching as a threat for the speaker, since code-switching would hinder any mastering of a language in use.

Yet, the Arabic language has to comply with the demands of new technologies. The analysis of tweets during the Tunisian revolution showed how Twitter has become a space of construction of a digital plurilingual citizenship, which invites sociolinguists to rethink their frameworks of analysis (GUELLOUZ 2017). ${ }^{4}$

The first linguistic issue after the 2011 revolution dates back to the very first days of the Constituent Assembly. The incident involved Karima Souid, a bi-national deputy belonging to the third generation of Tunisian immigrants in France, where she had grown up. Arriving in Tunisia right after the revolution, she spoke French. Her speech in the Assembly was met with a hostile response from conservative deputies. Omar Chattoui, one of them, harshly declared: "[...] no to Francophony. This is an insult to our parliament". Karima Souid reacted: "You are a racist, there is no law forbidding the use of French in this assembly and just to annoy you, I will always speak French". 5 In this linguistic fight, Karima Souid succeeded in imposing the idea of multilingualism as a part of "Tunisianity". She spoke French and Tunisian dialect as the representative languages of the Tunisian diaspora. She highlighted that, although linked to colonialization, French is also the language of Tunisian immigrants in Francophone countries as well as the scientific and academic language of Tunisian scholars and intellectuals. The conflict between French and Standard Arabic represents not only an opposition between two visions of the society, but also a quarrel between elites (GUELLOUZ 2017). French and Arabic are the languages of the highly educated elites who are struggling for power. With regard to the education system, article 39 of the Tunisian constitution of 2014 states:

The State shall ensure the consolidation of Arab-Muslim identity and national belonging to younger generations, the strengthening of Arabic language, the promotion of the latter and the generalization of its use. ${ }^{6}$

This also highlights the link between the strengthening of Arab-Muslim identity and the teaching of Arabic. As was the case in all previous Arabization reforms, Arabic is once more linked to Arab-Muslim identity and presented as a homogeneous, static entity. The political agenda, itself influenced by economic and ideological concerns, tried to orient linguistic practices. Several Tunisian intellectuals and academics sharply reacted to the adoption of article 39. Yet, they protested against Arabization while supporting the use of French, which

3 Digital writing has given rise to hybrid forms, where Arabic is written in Latin characters and some figures are added to replace the phonemes which do not exist in European languages.

4 See Myriam Achour Kallel's article in this volume (ACHOUR-KALLEL 2016).

5 <https://www.youtube.com/watch?v=Y73hAeLgsDo>.

6 <https://issafrica.org/ctafrica/uploads/TunisiaConstitution2014Eng.pdf>. 
is only mastered by highly educated Tunisians. The Francophone elite mirrored in this attitude the defenders of Arabization, seeking to establish a dominant language without taking daily linguistic practices into account.

\section{Linguistic issues in 2016}

2016 is a flourishing year for linguistic debates. On April 29, 2016, Fawzia Zouari, a Tunisian writer, published an article in Jeune Afrique magazine entitled "Francophony or Daesh". As the title suggests, F. Zouari regrets the decline of the French language in Tunisia, connecting it with two aspects: fundamentalist Islam and Arabization. The writer holds that the decline of French in Tunisia is related to the ascension of religious extremism. With this attitude, Zouari's linguistic analysis mirrors the linguistic imagery of Tunisian Francophone elites. For them, to be modern is synonymous with speaking French. They put aside all the economic and social issues and the disparity of access to education. The old Bourguibian idea that the French language guarantees access to modernity and progress seems to have persisted up to our epoch. These ideas are related to both pride and profit and they are economically determined because, on the one hand, speaking foreign languages is often an advantage for accessing the job market; on the other hand, learning languages is often a privilege of higher social classes. Gal explains how the axis of differentiation between national pride and economic profit is also linked to other factors, such as the dichotomy modernity/tradition or reason/passion (GAL 2012).

Nevertheless, no later than May 2016, Education Minister Naji Jalloul announced a new education reform based on the teaching of the Koran in primary schools during the summer holidays. This political decision aroused a wave of protests from the intellectuals, particularly the modernist francophone elite. One of the most important arguments presented by the education Minister to defend his reform was to mention that learning Koran is the best way to enhance Arabic language learning. He declared:

Tunisian students are no longer able to express themselves correctly either in Arabic or in foreign languages. I want to strengthen the learning of Arabic during the first three years of primary school. I also want to postpone the learning of foreign languages [French and English] until the fourth year. This aims to strengthen the implantation of Arab-Muslim identity. I shall submit this proposition within the national dialogue on education. ${ }^{7}$

The relation between Arabization and Arab-Muslim identity is always emphasized in political speeches. Article 38 of the 2014 Tunisian constitution reads:

The State shall ensure the anchoring of Arab-Muslim identity and the Arabic language in order to promote it and generalize its use. ${ }^{8}$

Some Francophone cultural elites claimed the day of the promulgation of this article was a black day for "Tunisianity". In their protest against the use of Arabic, Tunisian intellectuals

7 <http://www.jeuneafrique.com/mag/234897/societe/arabisation-en-tunisie-la-guerre-des-langues-aura-t-elle-lieu/> .

$8<$ https://issafrica.org/ctafrica/uploads/TunisiaConstitution2014Eng.pdf>. 
regret the decline of French. However, none of them deals with the position of the Tunisian dialect. None of them asks for an institutionalization of this dialect or its recognition as an official language, and thus as a language taught at school. The linguistic conflict is embodied in the contradiction of its speakers. This contradiction reveals a certain relation to power. In fact, who does speak French today in Tunisia? Francophony is a socioeconomic issue. In Tunisia, French is the language of the educated elite. The use of French almost equals one's affiliation to the socio-cultural category "bourgeois" and "westernized". The linguistic policies undertaken by the political power encourage the dominant bourgeoisie to create a new standard language. However, who does create the norm and for whom is such a norm created? Speaking French is a "bourgeois" practice, as well as a tool of discrimination. It is a way to differentiate between the members of an elite who think they have the control over modernity and the "others" who do not have access to it. In Morocco, for example, the government decided to bury Arabic and to enhance French learning in the educational system. This political decision was positively welcomed by the intellectual elites in Tunisia. They called for an application of the Moroccan system without reflecting upon the degree to which this system is unfair. In fact, illiteracy in Morocco is more widespread than in Tunisia. However, "Tunisianity" is torn between the limit of the Arab-Muslim identity and the fantasy of Francophony. In this gap between identities, the Tunisian dialect is more vulnerable. But it is also diverse. There are several regional varieties, but the one recognized as standard is the dialect of the capital city which "has always been playing the role of the national model as it holds the highest degree of prestige even outside the capital" (SAYAHI 2011: 3).

One of the main features connected with this dialect, observed and analyzed by sociolinguists, lies in code-switching. Some linguistic analyses show that code-switching can occur both between French and Tunisian and between Modern Standard Arabic and Tunisian. For Walters, code-switching is an essential characteristic of the Tunisian dialect (WALTERS 2011). Moreover, one could even argue that code-switching is an essential characteristic of "Tunisianity". However, what is then the language of "Tunisianity"? From a prescriptive and normative point of view on languages, there can of course never be a perfect bilingualism. The only way to save French in Tunisia is probably to accept the use of a hybrid French, "contaminated" by Standard Arabic and Tunisian linguistic structures. As we have seen, linguistic Tunisianity essentially means also multilingualism and code-switching. Arabization is also part of "Tunisification" as French and Tunisian dialect. For Walters (WALTERS 2011), the French-Arabic code switching is a main characteristic of Tunisia itself. In other terms, it seems that code-switching is a sort of dialectical resolution of the linguistic conflict between French and Arabic. It would also be a sign of a dynamic, fluid, heterogeneous and hybrid identity. In this way, being linguistically Tunisian is surely defined by fragmentation and hybridity. It is time to deconstruct the concept of "Tunisianity" as a homogeneous identity or as a "community". "Tunisianity" does not exist as a practice; it is the product of a political construction linked to the desire for a standard homogenous language.

Another event marked the end of the year 2016 in Tunisia. The Minister of Education decided to prioritize English, instead of French, as the first foreign language learned at school. The Tunisian section of the British Council announced on its website on September 17, 2016:

Two agreements between the Ministry of Education and the British Council were signed on Friday, September 16, 2016, at the headquarters of the Ministry of Education. His excellence Mr. Neji Jalloul, Minister of Education, and Mr Robert Ness, the country Director of the British Council in Tunis, signed the first agreement, related to 
the reactivation of the project 'Connecting Classrooms', which is to establish partnerships between Tunisian and British educational institutions in pedagogical fields of culture and activation [sic]. The project aims also to contribute to the development of skills of pupils and secondary school teachers. ${ }^{9}$

Indeed, the project "Connecting Classrooms" intends to connect the United Kingdom with Tunisia by promoting English linguistic skills. Considered as a tool for social promotion, English is is presented in a second project, entitled "English for Employability". These initiatives were not well received by the defenders of Francophony, who highlighted the long friendship and cultural alliance between France and Tunisia, as well as bilateral economic interests linking the countries. The future will show whether or not this linguistic reform can be applied. In any case, the opponents of Arabization fight for the sake of another dominant language, which is French. Very few intellectuals and/or members of Tunisian elites defend the languages of the minorities. The Berber language is forgotten. Except for minor actions of young activists, "Berberity" is excluded from the debate on "Tunisianity". As for the Tunisian dialect, it is marginalized, stuck between self-denigration and a fantasy of authenticity.

\section{Conclusion}

The current linguistic conflict in Tunisia stages a fight between two dominant languages: Standard Arabic and French. Each serves the construction of a static, uniform and homogeneous identity. French and Standard Arabic are both languages of the elites, used by a relatively small group of educated people in a country which still suffers from a significantly high illiteracy. Access to multilingualism is still, even today, in 2016, the privilege of a dominant urban class. The linguistic struggle after the 2011 Tunisian revolution is a conflict between the languages of urban elites.

As for minor languages, any attempt to instigate a real debate about them is denied. In the present article, I have tried to move beyond the notions of diglossia or code-switching in order to rethink the contacts between languages as a linguistic practice which reveals the relations of power between the speakers themselves, but also between the speakers and the institutions. From the point of view of linguistic conflicts, 2016 has been a year of very important yet very controversial educational reforms. The return to standardization of Arabic through teaching, the noticeable decline of the use of French and the emergence of English as a new alternative indicate linguistic policies in which multilingualism is becoming the new norm. Tunisian Arabic and Berber are perhaps the forgotten languages in these elite debates. Tunisian Arabic continues to survive in everyday practice, artistic productions and cultural heritage, with the risk of being limited to a romantic perception of national pride or to an artificially constructed sense of belonging. The coming years will allow us to depart from this romantic perspective, very often evident in the speeches of pro-Tunisian language activists, in order to reflect on the possibility of giving Tunisian Arabic an institutional framework. I would like to end this paper by making reference to the most emblematic term of the Tunisian

9 <https://www.britishcouncil.tn/en/about/press/signature-two-agreements>. 
revolution: "dégage". Although it is a French word, "dégage" has been exported to the rest of the Arab world as a Tunisian statement, particularly because of its phonetic alteration ("digage"). In this context, Mabrouka Mbarek, member of the Tunisian Constituent Assembly, asked to insert the term "dégage" in the introduction of the new constitution of 2014 on the basis of its stylistic and poetic endorsements. She declared: "the word "dégage" was the voice of the Tunisian revolution in the world" (GuELLOUZ 2017). "Tunisianity" would be defined by a language which would escape the political and economic agendas of the nationstate, admitting heterogeneity in its status of subversive and minor language: a language which entails, in 2016 and forever, the poetics of revolution.

\section{Bibliography}

ACHOUR-KaLLEL, Myriam. 2016. “«La Rolls et la Volkswagen » : Ecrire en tunisien sur Facebook en 2016". JAIS, 16: 253-272.

BOUlAABI, Ridha (dir.). 2017. Francophonies méditerranéennes XXIème siècle. Edition Geuthner.

BouRdieu, Pierre. 1982. Ce que parler veut dire. Fayard, Paris.

DAOud, Mohamed. 2011. "The Sociolinguistic Situation in Tunisia: Language Rivalry or Accommodation?” In: SAYAHI (ed.) 2011: 9-35.

GAL, Suzan. 2012. "Sociolinguistic regimes and the management of diversity". In: DuCHENE \& HeLLER (eds.) 2012: 22-42.

GonZALEZ-QuiJAno, Yves. 2012. Arabités numériques : le printemps du web arabe. Actes Sud/Sindbad, coll. Sindbad, Arles.

GuELlouz, Mariem. 2017. "La francophonie comme enjeu politique dans les débats à l'assemblée constituante dans la Tunisie post événements révolutionnaires". In: BOULAABI (dir.) 2017.

HELLER, Monica. 2008. "Language and the nation-state: Challenges to a sociolinguistic theory and practice", Journal of sociolinguistics, 12/14: 504-524.

Houdebine, Anne Marie. 2002. L'imaginaire linguistique. L'Harmattan, Paris.

LAROUSSI, Foued. 1997. Plurilinguisme et identités au Maghreb. Université de Rouen.

NAFFATI, Habiba / QuefFelec, Ambroise. 2004. "Le français en Tunisie". Le Français en Afrique [Institut de linguistique française, CNRS, UMR 6039-Nice], 18: 437-452.

RigueT, Maurice. 1984. “Attitudes et représentation liées à l'emploi du bilinguisme-Analyse du cas Tunisien”. Langages et langues, Publication de la Sorbonne, Paris.

SAYAHI, Lotfi (ed.). 2011. The Sociolinguistics of Tunisia. Special issue of International Journal of the Sociology of Language [De Gruyter Moutin].

SAYAHI, Lotfi. 2014. Diglossia and Language Contact. Cambridge.

WALTERS, Keith. 2011. "Gendering French in Tunisia: Language Ideologies and Nationalism". In: International Journal of Sociology, 211: 83-111. 